What is phenomenology? A review

\author{
G E Berrios MD FRCPsych Department of Psychiatry, University of Cambridge, Level E4 Spur, \\ Addenbrooke's Hospital, Hills Road, Cambridge CB2 2QQ
}

Keywords: phenomenology; Husserl; description; philosophy

The term 'phenomenology' refers to a set of philosophical doctrines loosley sharing: (a) assumptions as to what the world is like (metaphysical) and how it can be known (epistemological), and more importantly, (b) strategies for the descriptive management of the mental entities relating to such a world. They all strive to 'capture' 'experiential essences' which are but higher forms of knowledge (coveted 'epistemological' building bricks) with which the phenomenologist expects to reconstruct reality on a firmer footing. As against what is usually believed in clinical circles, phenomenologists have never been interested in the obtainment of tame, and (let alone) theory-neutral descriptions.

The Greek stems 'Phainomenon' (to appear), and 'logia' (discourse) ${ }^{1}$ were first combined in 1764 into the German word 'Phänomenologie' by J H Lambert (1728-1777) to refer to his 'theory of illusion or appearance'2. Kant, Hegel, Whewell, Hamilton, Mach, Brentano, and later on Husserl, appropriated the term to describe categories of their $\mathrm{own}^{3}$. As a consequence, the term has become a semantic palimpsest; knowledge of its constituent layers of meaning is, however, of little use to a clinician wanting to understand why some psychiatrists are so fond of using the term 'Phenomenology' in everyday discourse.

\section{The meanings of phenomenology}

At least four meanings can be distinguished. The first, $P_{1}$, refers to the ordinary clinical usage hinted at above, as a synonym for 'signs and symptoms' (as in 'describe for me the phenomenology of this patient'). This usage is conceptually uninteresting, a consequence of self-inflicted confusion and, to a certain extent, parasitical upon $P_{3}$ (below).

The second, $P_{2}$, refers to the quasi-technical sense in which the word is dealt with in dictionaries and encyclopaedias, which achieve spurious unity in the chronological cataloguing of successive meanings. $P_{2}$ suggests a false evolutionary line, and begs questions with regard to the history of phenomenology.

The third, $P_{3}$, refers to the idiosyncratic usage started by Karl Jaspers (1883-1969) who dedicated his early writings to the description of mental states in a manner which (according to him) was empathic and theory-neutral ${ }^{4,5}$.

Finally, $\mathrm{P}_{4}$, refers to the meandering philosophical system developed by Edmund Husserl (1859-1938), and continued by the work of a motley group of writers collectively called the 'Phenomenological Movement'6,7.

Of these, only $\mathrm{P}_{4}$ (in its early Husserlian version) will be dealt with in this paper as, according to many writers (and indeed Jaspers himself), is the intellectual source of what has since been called Jaspersian phenomenology ${ }^{8-12}$.

Since the turn of the century, phenomenology has sought to answer at least three questions: how do consciousness and its contents relate to the external world? How is it possible to differentiate mental from physical phenomena? And how can mental phenomena be individuated, ie distinguished from each other?

F Brentano (1838-1917) and W Dilthey (1833-1911) In the 1880 s these three questions were rephrased in psychological language. Brentano and Dilthey asked: why cannot 'analytical psychology', (the popular psychology of the period), offer adequate conceptual machinery to deal with the mind? More specifically, Brentano wanted to know whether psychology could differentiate mental from physical objects ${ }^{13}$. Dilthey, in turn, wanted to know whether a definition of 'personal experience' could be made available to help the historian to understand and explain historical events ${ }^{14}$.

Brentano ${ }^{15}$ believed that mental acts could be differentiated from physical entities in terms of their object: 'every mental phenomenon is characterized by what ... . we might call reference to a content, direction toward an object, or immanent objectivity. Every mental phenomenon includes something as object within itself .... In other words, 'intentionality' was the characteristic of mental phenomena (see below).

To handle this new conception of mental phenomenon, special descriptive methods were required. Brentano hoped that, once tooled, the latter would give rise to a new form of psychology ${ }^{13}$ which first he termed 'descriptive', and after 1888, 'phenomenological'. Dilthey ${ }^{16}$ believed that because 'analytical' psychology was based on a model borrowed from the natural sciences, it was incapable of dealing with mental experiences; hence he endeavoured to replace it by a new form of psychology which he also called 'descriptive'. Dilthey's proposal was savagely attacked by Ebbinghaus ${ }^{17}$. Rather dispirited, he ceased in his endeavours although took consolation in the belief that his views were in tune with early phenomenological writings. Husser $1^{18}$ acknowledged this similarity in his 1925 Lectures.

\section{'Intentionality' and the mental act}

A central philosophical issue at the turn of the 19th century was the nature of the relationships between mental act, its content and the external world. 'Mental act' means in this context 'mental experience' or 'mental event' (but not 'act' in the sense of activity). In fact, during this period the opposite of the word
Based on lecture to Section of Psychiatry, 8 March 1988
0141-0768/89/ 070425-04/\$02.00/0 (C) 1989 The Royal Society of Medicine 
act was not passivity but potentiality. Mental states could be 'actualized' (mental acts proper) or 'nonactualized', and both were 'intentional'. By the latter term early phenomenologists did not mean 'doing something on purpose', but (returning to its medieval sense), meant 'picturing or being directed to something'. So 'intentionality' was defined as the ability of the human mind to refer to objects outside itself $^{19,20}$.

Now, with regard to the relationships between mental act, its content and the external world, the received model (originally proposed by the British empiricists) stated that the external world was the only source of knowledge, and that its information, conveyed to the subject by the windows of his senses, constituted the mental experience. First Hobbes, Locke, Berkeley, and Hume, and later Kant and Reid, had all made use of the three-stages model. These great men had only disagreed on the informational (ie epistemological) contribution of each of the components.

\section{The individuation of mental acts}

Mental acts, however, needed to be individuated, ie distinguished from one another. For example, Dilthey wanted psychology to develop ways of ascertaining personal experiences and meanings rather than seeking general laws to account for classes of experiences ${ }^{14}$. Mental acts, however, seemed less amenable to the techniques used to individuate physical objects (ie detailed description or identification of spatio-temporal coordinates). In fact, at the end of the 19th century the individuation of mental acts was still based on knowledge of: (1) what object the act was directed to, and (2) its psychological mode, (ie whether the subject entertained it as an idea, feeling or volition).

These criteria, however, did not help to answer the question where does the information on which the individuation process is based come from? The solution, until the end of the 19th century, had been the so-called 'object theory' according to which information came from the object pictured by the mental act ${ }^{21}$. This view was unable to handle the problem of objectless mental contents, such as hallucinations or unicorns. Brentano, who has so often been mentioned as the father of phenomenology, upheld a variant of 'object theory' ${ }^{13}$ and Husserl was to criticize him for $i t^{22}$.

A solution to the problem of 'objectless' mental contents was offered by the great logician Gottlob Frege (1848-1925) in his paper 'On sense and reference' ${ }^{23}$. Frege was not, of course, concerned with mental acts but with the issue of linguistic reference ${ }^{24}$; and distinguished between an expression, its sense and its referent (ie the mental act, its content and the object) (p 58). Frege's model was imported into phenomenology as the 'content theory of intentionality'21. According to this theory the mental act was to be individuated in relation to its content, not its object. The mental act itself, however, was directed to the referent (object). Frege's emphasis on 'sense' as something which many people (indeed everyone) might hold in common was not lost to phenomenology. It provided the epistemological terra firme on which to take a stand against 'psychologism'.

\section{Psychologism: origins and problems}

According to 'psychologism' (a popular philosophical position during the 19th century) there only could be individual minds and ideas but not universally shared meanings. Related to this was the belief that mathematics and logic (like all other forms of thinking), were subjected, in the final analysis, to the laws and processes of psychology. Hence, their epistemological foundations were to be sought, not in some $a$ priori given, but in the empirical study of cognition.

The issue of the relationship between psychology and epistemology had received only temporary solution in the work Descartes and Locke. In the former, by means of the use of a Divine rule; in the latter, by subsuming the problem into his own version of psychology 25 . Both views were challenged during the Enlightenment, and solutions offered by men like Condillac and Kant gained only partial acceptance ${ }^{25}$.

Psychologism re-appeared in Germany early in the 19th century sponsored by J F Fries (1783-1844) ${ }^{26}$ and F E Benecke (1798-1854) ${ }^{27}$, and somewhat later in England, under the auspices of JS Mill (1806-1873). In the latter's case it was as a reaction against Hegel and Kant, particularly against Kant's classification of judgments into empirical, analytical and synthetic a priori. Empirical statements depended for their truth on the external world, and analytic statements for theirs on the clarity of their definitions. The nature of the third type of statement (ie synthetic a priori), however, was less clear for they were supposed to contain information about the world, although obtained by means other than direct experience (eg intuition). Mills ${ }^{28}$, in the event, reduced all analytical and synthetic a priori judgments to empirical statements, ie stated that even the truth of logic and mathematics depended upon the experiencing of such relationships in the real world (p 370).

In the late 19th century psychologism was pushed further: if the truth of all statements depended upon empirical testing, then logical demonstration no longer sufficed. Psychology, the only science of the mind, was charged with testing all principles. But since (by definition) all empirical statements could be true or false, then there was the possibility that logical principles and mathematical relationships could also be false. This reduction of logic and mathematies to psychology was strongly resisted.

One of the first to do so was Frege. Brought up in this intellectual environment, it is not surprising that Husserl hesitated between the two positions. Indeed, his earliest writings have been interpreted as defending a version of 'psychologism'. For example in his book on the 'philosophy of arithmetic' 29 he defended the so called 'theory of abstraction' which was an empiricist attempt to explain how the concept of 'general term' is acquired, and which received a severe rebuke from Frege ${ }^{30}$.

\section{Husserl}

Husserl's work can be divided into three periods. The earliest is the 'psychological' period, during which he attempted to provide a psychological foundation for the eternal truth of numbers ${ }^{29}$. The end of this period is marked by Frege's review ${ }^{30}$ (see p 317). The second or middle period, containing the full development of his phenomenological views as stated in 'logical investigations' 31 and 'ideas', 32 comes to an end with the writing of 'formal and transcendental logic'33. This period is the longest, and includes an earlier and later parts. The third period culminates in 1936 with the almost mystical book on "The crisis 
of European science ....34. Of the three periods, only the earlier part of the second one might be of relevance to the history of psychopathology. The third, through the influential deviationism of Heidegger, contributed to the development of the so-called 'existential psychoanalysis'35; it will not be treated further in this paper.

There is, to be sure, some disagreement as to the extent of Husserl's 'psychologism'. Frege ${ }^{30}$ seems to have considered it as clear, and Osborn ${ }^{36}$ (p 33), and Farber $^{37}$ agree ( $p$ 89). Spiegelberg ${ }^{7}$ sees Husserl's psychologism as an earlier aberration but still refers to his 'pre-phenomenological period' (p 85). Schmidt ${ }^{38}$ has seen the 'philosophy of arithmetic', as an attempt at 'a psychological analysis of certain basic logical and mathematical notions' (p 97). On the other hand, Boer $^{22}$, Kelkel and Schérer ${ }^{39}$ and Dartigues ${ }^{3}$ believed Husserl took an anti-psychologistic stance from the beginning.

It seems clear, however, that what Spiegelberg ${ }^{7}$ has called Husserl's 'striking shift' (p 85) marked a move away from his earlier ideas and a decision to take a clear stance against psychologism. This he did after 1895. The so-called phenomenological method is not yet mentioned in this first period and hence it is unlikely to be of much relevance to psychopathology, indeed Jaspers does not refer to any writings from this early period ${ }^{4}$.

The early part of the second period may be of some importance to descriptive psychopathology. After 1895 Husserl started developing his content theory and phenomenological method. The former was based upon the view that (1) all intentional acts have content; (2) the content determines to which object the acts refer; (3) there are objectless acts, ie the content of an act may fail to determine an object for the act in question ${ }^{21}$. With regard to method Husserl ${ }^{18}$ stated: 'we can exercise phenomenological reduction on every perception belonging here, therefore on every external, transcendental perception, precisely as a methodical operation of reduction to the purely immanent, to pure subjectivity' (p 143).

Husserl went on to offer ever more refined distinctions. On his death he left an unfinished and complicated collection of views. Husserlian phenomenology rehearsed solutions to problems in areas as diverse as metaphysics, referential logic, epistemology and the philosophy of mind; all of which, at the time of its inception, were hidden under the problem of the scope of psychology. Since those early days followers of phenomenology have wandered far afield to apply their method in sociology ${ }^{40,41}$, experimental psychology ${ }^{42}$, history and politics ${ }^{43,44}$, philosophical anthropology ${ }^{46,46}$, and psychoanalysis ${ }^{35}$.

\section{Phenomenological 'description' and psychiatry} It is important to distinguish between the phenomenological and conventional meanings of 'description', as their confusion has generated much misunderstanding. Descriptions in phenomenology are not meant to collect itemized information on the world or to form the basis for empirical statements of the kind that might be considered as relevant to science or scientific psychopathology ${ }^{4,6,47}$. In fact, phenomenological descriptions apply only to subjective experiences; thus, objective clinical changes such as psychomotor retardation, tremor, catatonia or soft neurological signs, fall beyond its epistemological and methodological scope. For the capturing of 'experiential essences' the phenomenological method of description relies on the exercise of special human faculties such as intuition and empathy; indeed, observational strategies based on the sense modalities (and measurement techniques) tend to be discouraged.

From the point of view of the clinician, perhaps, the more difficult point to deal with relates to 'immutable essences' which can either be interpreted as operational definitions ${ }^{48}$ or as metaphysical entities. The dilemma here is that, if the former is the case, the adjective phenomenological adds little to the descriptive exercise; if the latter, it might prove to be too high a metaphysical price to pay.

\section{Discussion and conclusions}

It should be clear by now that the question - what is phenomenology? - must be qualified by stating whose, and in what period, before it can be given a sensible answer. Like any other philosophical school phenomenology developed partially under its own impetus, and partially as a reaction to ongoing adversarial dialogues; hence knowledge of the intellectual context is important; for example, to explain why it failed to thrive in England6.

For the clinician seeking clear-cut answers, the convoluted and occasionally dense nature of the phenomenological writings, may prove off-putting and lead, perhaps unfairly, to the conclusion that nothing scientific can come out of it. Whether or not this conclusion is warranted remains to be seen. More to the point, the historical question of as to whether phenomenology really influenced Jaspers is badly in need of further research ${ }^{4,5}$.

One point is plain, to wit, that in view of what has been said above, it is difficult to accept the claim that phenomenology was, is (or ever will be) just a sophisticated method of description, unless, of course, the term 'description' is used in a very idiosyncratic fashion. From a technical viewpoint, the issue is whether it is possible to find in phenomenology anything that can meaningfully be recognized as a pure (atheoretical) 'method' of description ${ }^{49}$. It is likely that such 'method' never existed.

It should be concluded, therefore, that there is little in the philosophical movement called phenomenology (as developed by Husserl and continued by his followers) which is conceptually useful to the construction of a modern theory of description applicable to the signs and symptoms of mental or physical illness. This statement should not, however, be allowed to prejudice the wider claim that phenomenology (like psychoanalysis or Marxism) remains one of the great intellectual achievements of Western culture.

\section{References}

1 Klein E. A comprehensive etymological dictionary of the English language, vol II. Elsevier: Amsterdam, 1967

2 Cassirer E. El problema del Conocimiento en la filosofia $y$ las ciencias modernas, vol 2 (translated from the original 1907 German edition by Roces W). México: Fondo de Cultura Económica, 1956;487-98

3 Dartigués A. Qu'est-ce que la phenomenologie? Paris: Privat, 1972

4 Berrios GE. Phenomenology, psychopathology and Jaspers. Am J Psychiatry, 1990 (in press)

5 Berrios GE. Descriptive psychopathology: conceptual and historical aspects. Psychol Med 1984;14:303-13 
6 Berrios GE. Phenomenology and descriptive psychopathology: was there ever a relationship? Psychol Med 1988 (in press)

7 Spiegelberg $\mathrm{H}$. The phenomenological movement, 3rd revised and enlarged edn. The Hague: Martinus Nijhoff, 1982

8 Heimann H. Der Einfluss von Karl Jaspers auf die Psychopathologie. Psychiatrie Neurologie 1950;120:1-20

9 Taylor FK. The role of phenomenology in psychiatry. Br J Psychiatry 1967;113:765-70

10 Berner $P$, Kufferle B. British phenomenology and psychopathological concepts. $\mathrm{Br} J$ Psychiatry 1982; 140:558-65

11 Shephard M. Karl Jaspers: general psychopathology. $\mathrm{Br}$ J Psychiatry 1982;141:310-12

12 Jaspers K. Die phenomenologische Forschungsrichtung in der Psychopathologie. Zeitschrift für die gesamte. Neurol Psychiatr 1912; 9:391-408

13 Rancurello AC. A study of Franz Brentano. New York: Academic Press, 1967

14 Hodges HA. The philosophy of Wilhelm Dilthey. Wesport, Connecticut: Greenwood Press, 1952

15 Brentano F. (version consulted: In: eds Kraus $O$, McAlister LL, Psychology from an empirical standpoint. translated by Rancurello AC, Terrell DB, McAlister LL. London: Routledge \& Kegan Paul, 1973:88) 1874

16 Dilthey W. Ideen uber eine beschreibende und zergliedernde Psychologie. Sitzungsberichte der Preuss. Ak. der Wissenschaften, pp 1309-1407 (version consulted: Gesammelte Schriften, 5, Stuttgart: Teubner, 1957: 139-237) 1894

17 Caparros A. H. Ebbinghaus. Un funcionalista investigador tipo dominio. Barcelona: Edicions de la Universitat de Barcelona, 1986

18 Husserl E. Phenomenological psychology. (translated by Scanlon J). The Hague: Martinus Nijhoff, 1977:25

19 Spiegelberg H. Der Begriff der Intentionalität in der Scholastik, bei Brentano, in bei Husserl. Philosophische Hefte 1936;5:75-91

20 Chisholm RM. Intentionality. In: Edwards P, ed. The encyclopedia of philosophy, vol 4. New York: MacMillan, 1967:201-4

21 Sajama S, Kamppinen M. A historical introduction to phenomenology. London: Croom Helm, 1987

22 Boer T de. The development of Husserl's thought (translated by Plantingat) The Hague: Martinus Nijhoff, 1978

23 Frege G. On sense and reference. (version consulted: In: Geach P, Black M, eds and translators, Philosophical writings of Gottlob Frege. Oxford: Blackwell, 1966:56-78) 1892

24 Dummett M. Frege. Philosophy of language. London: Duckworth, 1973:58

25 Cassirer E. Filosofia de la Ilustracion. Mexico: Fondo de Cultura Económica, 1950:112-54

26 Cassirer E. El problema del conocimiento en la filosofia $y$ en las ciencias modernas. Vol III. Los Sistemas PostKantianos (being a translation of the original 1920 German edition by Roces W) Mexico: Fondo de Cultura Económica, 1957:532-72

27 Windelband W. Historia de la filosofia moderna, vol 2. Buenos Aires: Nova, 1948:318-28

28 Mill JS. A system of logic. (8th edn. London: Longmans, Green, and Co, 1898) 1843

29 Husserl E. Philosophie der Arithmetik. Psychologische und Logische Untersuchungen, vol 1. Halle-Saale, 1891
30 Frege G. Review of Husserl's Philosophie der Arithmetik. Zeitschrift für Philosophie und philosophische Kritik 1894;103:313-32 (version consulted: translation in Geach P, Black M, eds. Philosophical writings of Gottlob Frege. Oxford: Blackwells, 1966:79-85

31 Husserl E. Logische Untersuchungen (work consulted: Investigaciones Logicas, a translation of the 2nd German edition, 1913 by Morente MG \& Gaos J. Madrid: Revista de Occidente, 1929) 1900

32 Husserl E. Ideen zu einer reinen Phänomenologie und phenomenologischen Philosophie. Niemeyer, Halle (work consulted: Ideas relativas a una fenomenologia pura y una filosofia fenomenologica, a translation of the second German edition of 1950 by Gaos J. México: Fondo de Cultura Económica, 1949) 1913

33 Husserl E. Formale und transzendentale Logik. Versuch einer Kritik der Logischen Vernunft (work consulted: 2nd edition, Husserliana Vol 17, The Hague) 1929

34 Husserl E. Die Krisis der europaischen Wissenschaften und die transzendentale Phänomenologie(work consulted: The crisis of European science, translation by Carr D. Evanston 1970) 1936

35 May R, Angel E, Ellenberger HF, eds. Existence. A new dimension in psychiatry and psychology. New York: Basic Books, 1958

36 Osborn AD. Edmund Husserl and his logical investigations, 2nd edn. Cambridge, Massachusetts, Harvard University Press, 1949

37 Farber M. The foundations of Phenomenology. Edmund Husserl and the quest for a rigorous science of Philosophy. Cambridge: Harvard University Press, 1943

38 Schmidt R. Edmund Husserl. In Edwards P, ed. The Encyclopedia of philosophy, vol 4. New York: McMillan, 1967:96-9

39 Kelkel L, Schérer R. Husserl. Paris: Presses Universitaires de France, 1964

40 Gorman RA. The dual vision. Alfred Schutz and the myth of phenomenological social science. London: Routledge \& Kegan Paul, 1977

41 Roche M. Phenomenology, language and the social sciences. London: Routledge \& Kegan Paul, 1973

42 Thinès G. Phenomenology and the sciences of behaviour. London: George Allen \& Unwin, 1977

43 Tran-Duc-Thao. Fenomenologia y materialismo dialéctico. Buenos Aires: Lautaro, 1959

44 Mays W. Phenomenology and marxism. In: Pivcevic E, ed. Phenomenology and philosophical understanding. Cambridge: Cambridge University Press, 1975:231-50

45 Blankenburg W. A dialectical conception of anthropological proportions. In de Koning AJJ, Jenner FA, eds. Phenomenology and psychiatry. London: Academic Press, 1982:35-50

46 Zutt J. Aus dem Wege zu einer anthropologischen Psychiatrie. gesammelte Aufsätze. Berlin: Springer, 1963

47 Szilasi W. Wissenschaft als Philosophie. Zurich: Europa, 1945

48 Jennings $\mathrm{JL}$. Husserl revisited. The forgotten distinction between psychology and phenomenology. Am Psychol 1986;41:1231-40

49 Funke G. Phenomenology: methaphysics or method (translated by Parent D). Athens: Ohio University Press, 1988

(Accepted 15 September 1988. Dedicated to the memory of Max Hamilton, who on the occasion of attending the lecture on which this paper is based, delighted us, as always, with the fireworks of his wit and intelligence) 